\title{
Proceeding
}

9th INSHS International Christmas Sport Scientific Conference, 4-6 December 2014. International Network of Sport and Health

Science. Szombathely, Hungary

\section{Longitudinal monitoring of performance in cross- country running by young orienteering runners}

\author{
IVAN RUZICKA \\ Department of Physical Education and Sport, Faculty of Education, University of Hradec Kralove, Czech Republic
}

\begin{abstract}
Ruzicka, I. (2015). Longitudinal monitoring of performance in cross-country running by young orienteering runners. J. Hum. Sport Exerc., 9(Proc1), pp.S269-S278. The aim of this paper focused on the one of platform of the system for regular work with talented children and youth on the field of the orienteering. The article brings partial results of longitudinal testing talented youth of East Bohemian region of the Czech Republic in orienteering. 10 - 14-year orienteering talented runners took part in testing motor skills standardized tests. The text approaches the methodology and presents the selected results of the measurement - the performance in cross-country running test at $3 \mathrm{~km}$ and $5 \mathrm{~km}$ depending on age category as one of the many tests that young athletes participating always at the beginning of the season. Results of the research show a significant difference among selected athletes and indicate tendencies performance in cross-country running of youth orienteering runners in the region. The conclusions highlight the long-decreasing level of endurance abilities of young orienteering contestants between 1997 and 2014, describes the possible reasons and suggestions remedial options. Key words: LONGITUDINAL MONITORING, ORIENTEERING, MOTOR TESTING, MEASUREMENT, CROSS-COUNTRY RUNNING, TALENTED YOUTH.
\end{abstract}

Corresponding author. University of Hradec Kralove, Rokitanskeho 62, Hradec Kralove 3, 500 03, Czech Republic E-mail: ivan.ruzicka@uhk.cz 9th INSHS International Christmas Sport Scientific Conference, 4-6 December 2014. International Network of Sport and Health Science. Szombathely, Hungary.

JOURNAL OF HUMAN SPORT \& EXERCISE ISSN 1988-5202

(c) Faculty of Education. University of Alicante doi:10.14198/jhse.2015.10.Proc1.14 


\section{INTRODUCTION}

Diagnosis of assumptions about motor activity of humans is an irreplaceable object in the area of competitive sports (Thomas \& Nelson, 2001). Motor testing of motor skills of the readiness and subsequent utilization of gained results allows us to create a coherent system of elaborated work with the talented, especially with children and youth sport categories (Krištofič, 2006; Perič, 2006). Relevant diagnosis is usually not performed only in the areas which have a primary influence on the athletic performance, but regular monitoring and evaluation of the dominant area presupposing an athletic performance in a particular area are always considered to be a key aspect (Neuman, 2003).

In orienteering, it is primarily a factor of running endurance, which is the current level of functional capacity of the athlete in relation to the needs to achieve a quality performance (Hnizdil \& Kirchner, 2005). Based on the gained and recorded data, it is possible to frame a specific preparation program for a promising athlete - ant that is form the point of view of both the short-term programme and long-term preparation programme and its predicted results (Perič, 2004). Monitoring the results of motor testing of groups of talented youths from the long-term points of view also brings back feedback in the area of currents trends of specific endurance with the possibility of reactions and consequent expectations (Rủžička, 2009).

The systematic work with the sports base of children and youth in orienteering in the Czech Republic is one of the key areas of the support of the development of the sport industry. Specific emphasis on the care of young sporting talents is, in the long term, focused mainly in the largest area of orienteering in the Czech Republic - in the East Bohemian region. There the testing of young orienteering runners takes place under the supervision of experienced coaches of the regional selection for eighteen years already (with the exception of year 2001, when the testing failed to take place because of organizational reasons). The testing of talented youth of orienteering of East Bohemian region always take place at the beginning of the new season in April in the regional centre of the area, in Hradec Králové. Young promising orienteering runners at the age from 10 to 14 years are invited to this testing. These young runners have placed at least on the tenth position in girls $(\mathrm{G})$ and boys $(\mathrm{B})$ categories $\mathrm{G} 12 \mathrm{C}, \mathrm{G} 14 \mathrm{C}, \mathrm{B} 12 \mathrm{C}, \mathrm{B} 14 \mathrm{C}$, and first two from categories $\mathrm{G} 10 \mathrm{C}$ and $\mathrm{B} 10 \mathrm{C}$, in the preceding part of the autumn ranking of the area. The selected individuals then also participate in mixed training camps and they represent the region in the national team competition (Růžička \& Lamichová, 2010).

\section{MATERIAL AND METHODS}

The aim of the research is to evaluate the performance trends of young talented orienteering runners on the base of the results of long-term motor testing in cross-country running as an indicator of the level of preparedness in the area of endurance abilities, which are closely related to the competitive performance of the runners.

The tasks of this work were the evidence of the results of the cross test in individual examined categories and years, of the processing and graphical presentation of data gained by the measurements and expressing partial and general conclusions and recommendations for practice.

Following hypothesis was defined: We assume that the performance of all monitored categories in the cross-country running test will generally have a decreasing trend in monitored years 1997 - 2014. 


\section{Participants}

Over the eighteen years there were tested over 230 girls and 239 boys of categories $\mathrm{G} 12$ (girls under 12 years of age), G14 (girls under 14 years), B12 (boys under 12 years) and B14 (boys under 14 years) altogether. Talented individuals from categories G10 (girls under 10 years) and B10 (boys under 10 years) were assigned to the groups G12 (girls under 12 years old) and B12 (boys under 12 years). The testing takes place in a gym as well as outdoors. Day 1 of testing always takes place on Saturday afternoon on the first weekend in April after the regional rankings race, with the presence of coaches of talented pupils of the area and coaches of pupils of individual participating teams. The testing of running endurance is always held the next morning on the designated track, which remains unchanged throughout the whole longitudinal monitoring. The measurement of cross-country running is done by manual stopwatch accurate to a second.

\section{Measures}

The complete testing of talented youth of the East Bohemian region in orienteering consists of 5 tests of general physical readiness (Měkota \& Kovář, 1996; Měkota et al., 1995) and 1 test of special physical readiness. The structure of the tests is constant for the whole eighteen years and takes place at the same location.

The tests of general physical readiness consist of these items:

0 . Standing long jump (a jump to a maximum distance with jumper's feet put together; the monitored factor: the explosive strength of lower limbs)

1. A number of sit-ups in one minute (a max. number of sit-ups in 1 minute; the monitored factor: the trunk strenght)

2. Jumps both legs over the transversally placed bench in one minute (a max. number of vaults in 1 minute; the monitored factor: muscular endurance of the lower limbs)

3. Sit and reach (a maximum reach of fingertips; the monitored factor: flexibility)

4. Bent arm hang - boys / endurance in the bent - girls (a max. number of bents / a time of endurance in the bent arm position while hanging from a bar; the monitored factor: arm and shoulder muscular endurance)

By the special physical readiness test is meant the run in forest terrain - cross. Every year all categories run on the identical test track, girls (G12 and G14 categories) and younger boys (category B12) of a length of three kilometres, boy category B14 runs five kilometres long track. The test track consists of circuits of length of $1 \mathrm{~km}$ and an elevation of $20 \mathrm{~m}$, and is lead along forest paths and open terrain. The tests are carried out after a thorough warm-up and the whole testing process is taking place under the supervision of trained coaches.

\section{Analysis}

The research is based on quantitative analysis. Data were organized and processed by means of mathematical and statistical methods using computer software Microsoft Excel.

In terms of presentation, graphical methods are used, individual results are converted into clear line charts using line display of the trend of the performance. To evaluate and interpret the results and expressing of conclusions, basic logical methods are used. 


\section{RESULTS}

In the Course Navette test the average of the initial lactate was $4.9 \pm 2.1 \mathrm{mmol} / \mathrm{L}$ and $11.6 \pm 3.3 \mathrm{mmol} / \mathrm{L}$, at the end. The average speed reached was $12.8 \mathrm{~km} / \mathrm{h} \pm 0.8$, for a calculation of $\mathrm{VO}^{2}$ of $48.9 \pm 5.7 \mathrm{ml} / \mathrm{kg} / \mathrm{min}$, and the maximum heart rate was $193.8 \pm 9.3$ beats per minute. Final data for the Course Navette test are found in Table 2.

Table 1. Results of cross-country running testing of youth categories in individual years

\begin{tabular}{ccccc}
\hline \multicolumn{5}{c}{ CROSS $3 / 5 \mathrm{~km}$} \\
Year & G12 & B12 & G14 & B14 \\
\cline { 2 - 5 } 1997 & $\mathrm{~A}$ & $\mathrm{~A}$ & $\mathrm{~A}$ & $\mathrm{~A}$ \\
1998 & 16.23 & 14.87 & 15.00 & 22.95 \\
1999 & 15.47 & 14.88 & 15.00 & 23.62 \\
2000 & 16.43 & 14.78 & 14.98 & 23.97 \\
2002 & 16.23 & 15.80 & 14.90 & 23.97 \\
2003 & 15.87 & 15.83 & 15.00 & 23.23 \\
2004 & 15.58 & 15.01 & 14.25 & 24.52 \\
2005 & 15.32 & 14.97 & 14.55 & 23.63 \\
2006 & 14.67 & 14.22 & 14.25 & 23.20 \\
2007 & 16.38 & 15.73 & 14.97 & 23.68 \\
2008 & 15.65 & 15.90 & 13.68 & 25.00 \\
2009 & 15.60 & 15.00 & 15.30 & 23.83 \\
2010 & 16.97 & 15.27 & 15.97 & 25.75 \\
2011 & 18.95 & 16.78 & 16.76 & 26.10 \\
2012 & 17.80 & 15.09 & 15.39 & 22.81 \\
2013 & 16.44 & 16.26 & 15.35 & 24.12 \\
2014 & 16.40 & 16.33 & 15.60 & 24.88 \\
\hline
\end{tabular}

Legend: G12 - girls up to 12 years; G14 - girls up to 14 years; B12 - boys up to 12 years; B14 boys up to 14 years (categories of children and youth orienteering in the Czech Republic) $\mathrm{A}$ - an arithmetic average in individual years (data given in minutes converted into decimal system) 


\section{G12}

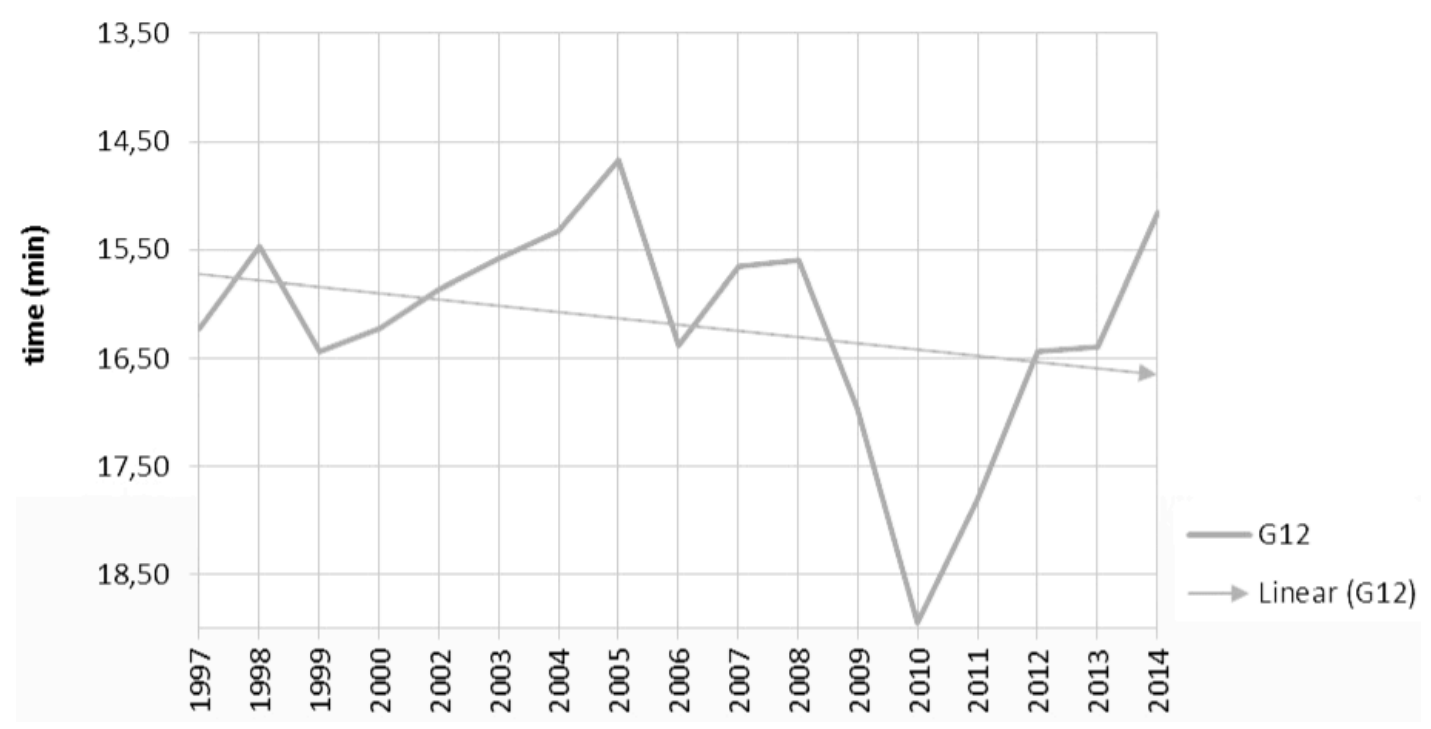

Figure 1. A curve of arithmetic averages of the performance in the category of the youngest girls G12 (distance $3 \mathrm{~km}$ ) tested in cross-country running in the years 1997 - 2014 and the presentation of the monitored linear trend in this category

B12

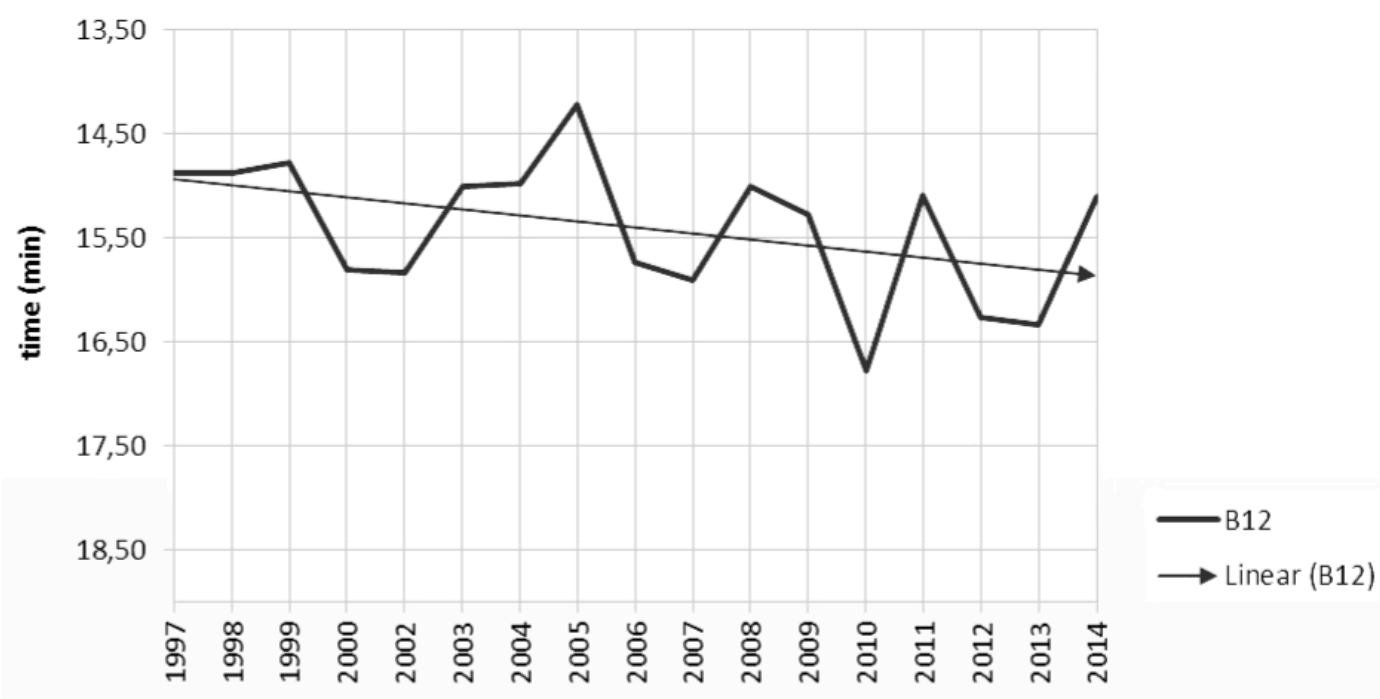

Figure 2. A curve of arithmetic averages of the performance in cross-country running testing and the presentation of the monitored linear trend in the category of the youngest boys B12 (distance $3 \mathrm{~km}$ ) 


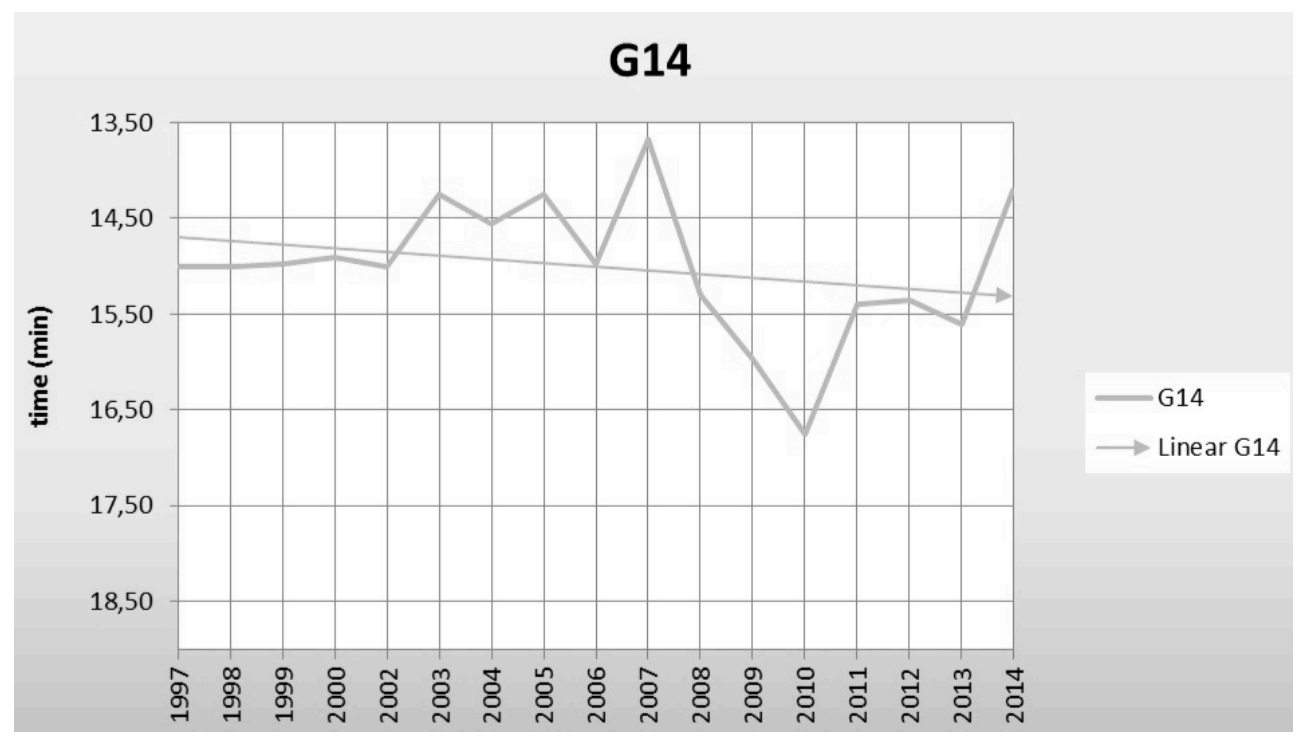

Figure 3. A curve of arithmetic averages of the performance in cross-country running testing and the presentation of the monitored linear trend in the category of the oldest girls $\mathrm{G} 14$ (distance $3 \mathrm{~km}$ )

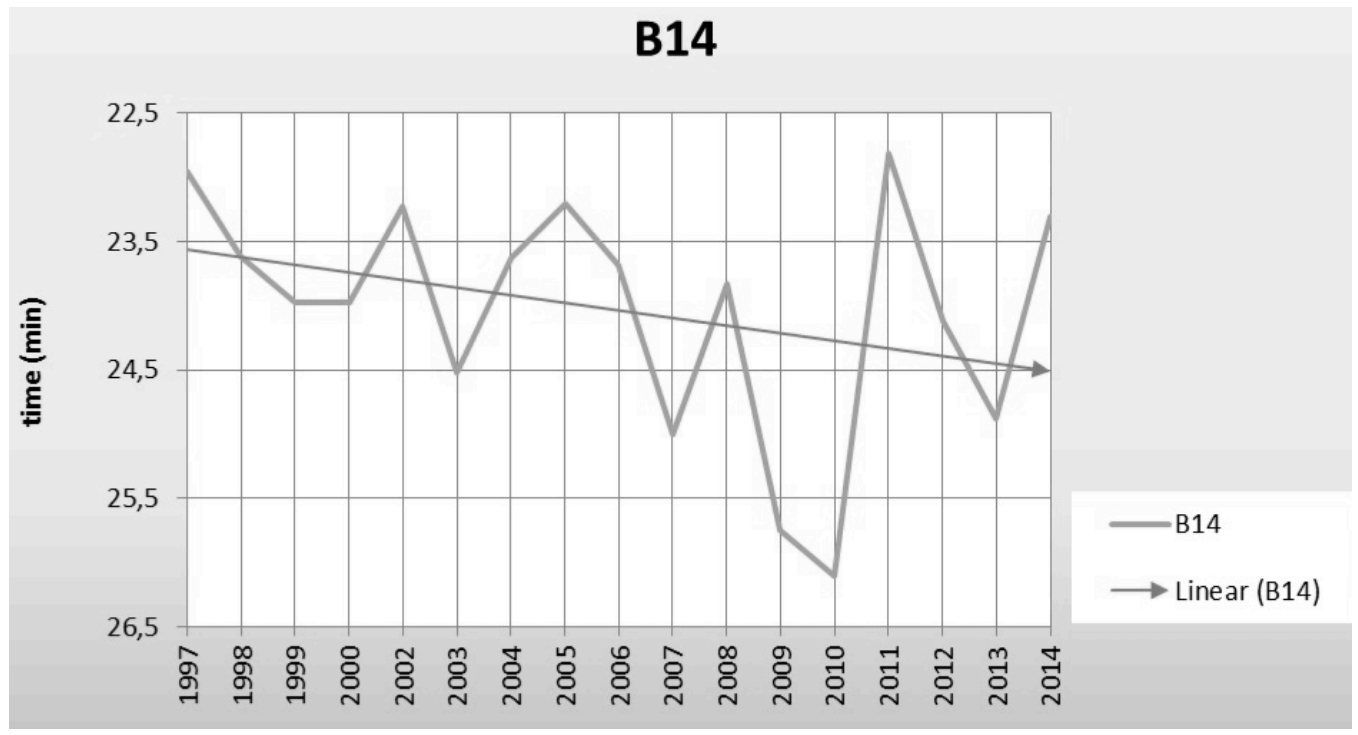

Figure 4. A curve of arithmetic averages of the performance in the category of the oldest boys B14 (distance $5 \mathrm{~km}$ ) tested in cross-country running and the presentation of the monitored linear trend in this category 


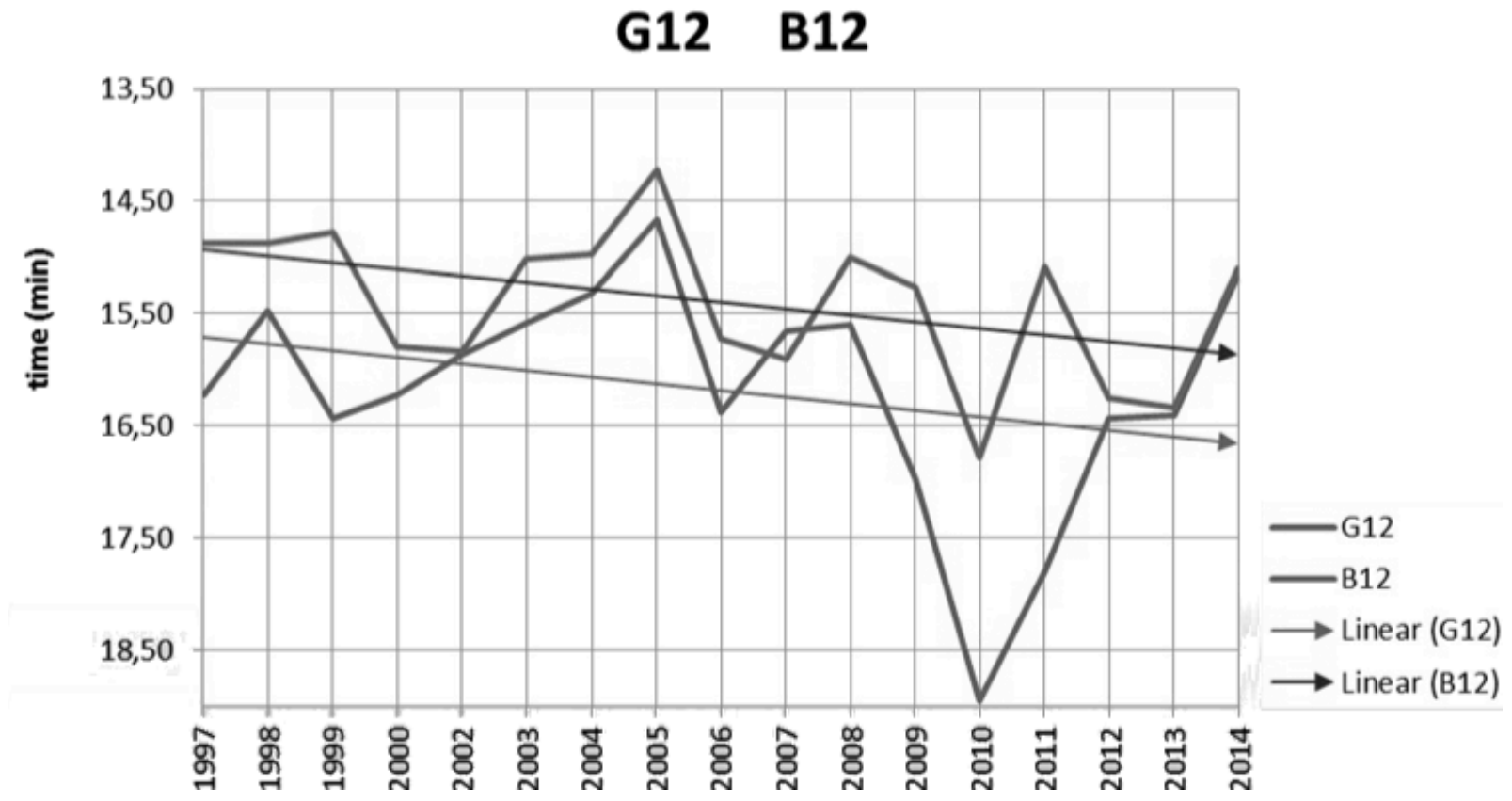

Figure 5. A comparisons of results of the youngest girls and boys categories ( $G 12$ and B12 - distance 3 $\mathrm{km}$ ) with the presentation of linear trends of performance

\section{G12 G14}

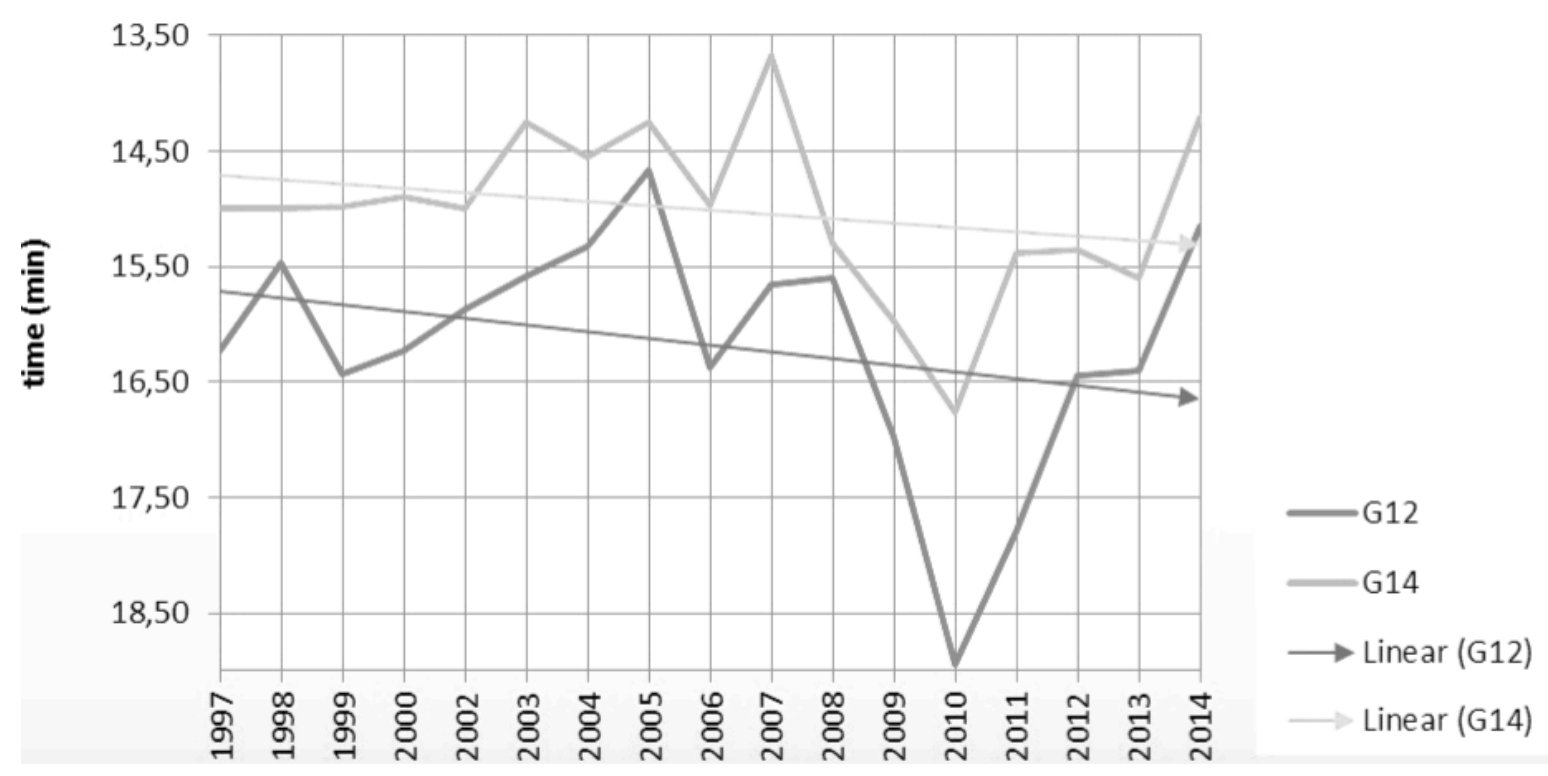

Figure 6. A comparisons of results of both monitored girls categories (G12 and G14 - distance $3 \mathrm{~km}$ ) with the presentation of linear trends of performance 


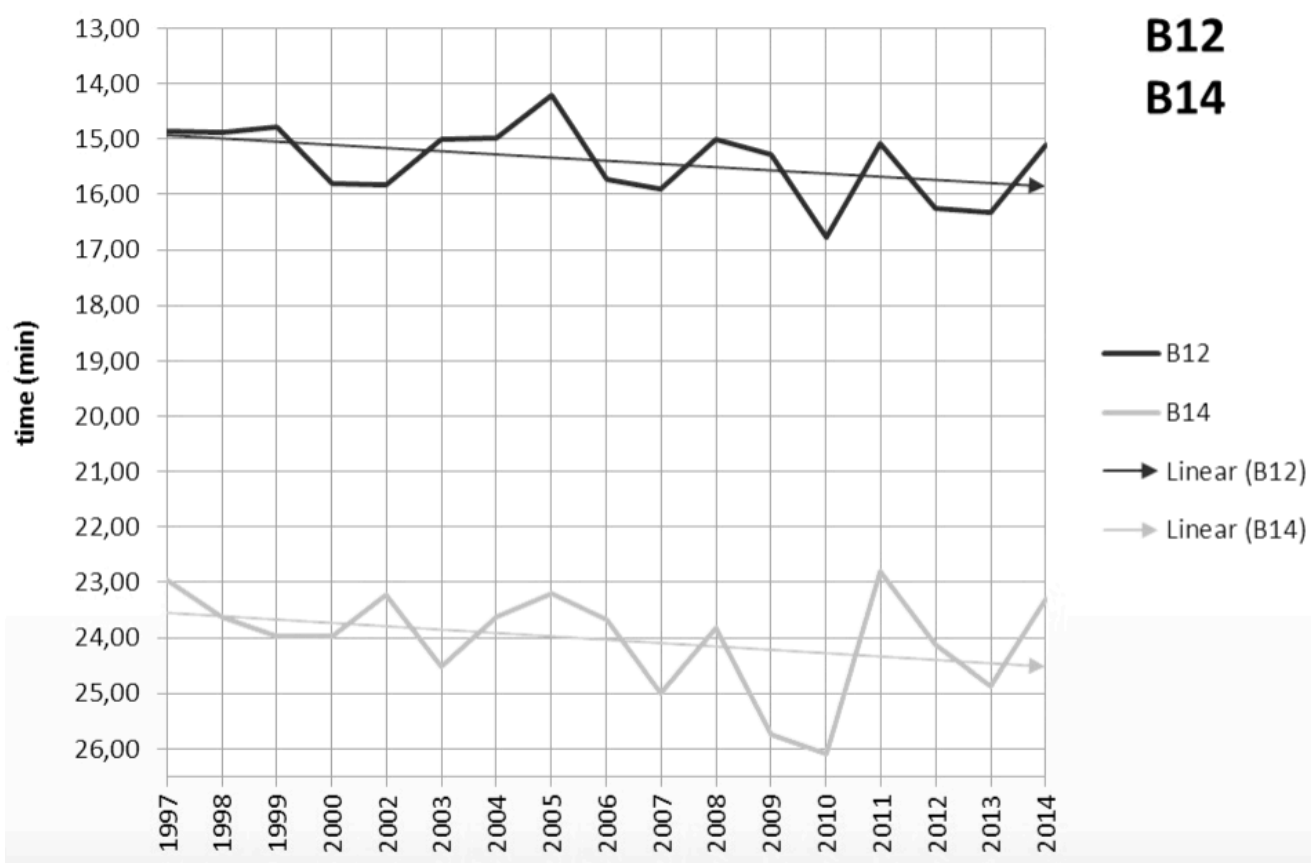

Figure 7. A comparisons of results of both monitored boys categories (B12 distance $3 \mathrm{~km}, \mathrm{~B} 14$ distance 5 $\mathrm{km}$ ) with the presentation of linear trends of performance

The above-mentioned graphs are showing the arithmetic averages of the cross-country endurance test for individual categories in each of the monitored years. The illustrated connector of the linear trend of the results indicates the tendency of performances in the monitored period $1997-2014$ in all tested categories of girls and boys, both on the $3 \mathrm{~km}$ track and $5 \mathrm{~km}$ for the oldest boys' category.

\section{DISCUSSION}

In G12 and B12 categories (Figure 5), we can observe a close correlation between the performance curves for the categories of girls and boys of the same age (competitors under 12 years). The close values of the results in most of the monitored years, namely between years 2000 - 2008 and from 2012 on, suggest an association in different degrees of motor maturity between girls and boys of the same age category (Moravec, 1990). In some years of the measurements girls achieve similar or identical performance in cross-country running test as boys; in r. 2007 we can even track an achievement of better average performances of girls than boys of the same age. This corresponds to the results by Hnizdil et al. $(2012,55)$ for this age category, who found out "...there are low differences of aerobic performance between male and female until 12 years of age." Male aerobic performance continues to rise after thirteenth year of age, however female performance begins to stagnate or even decreases (Máček \& Radvanský, 2011; Máček \& Vávra, 1988).

GB12 test results underline the need for understanding the difference between biological and chronological age of young athletes of both sexes and the necessity of individual planning and implementation of sports preparation training, especially when considering those categories (Perič, 2004; Krištofič, 2006).

The most significant decline in performance in all categories was recorded in 2010, with no obvious reasons for this decline, which would explain this fact sufficiently. Since no significant changes in conditions 
were noted during the testing compared to the other years (weather, the quality of the subsoil of the track etc.), it would be possible to look for the possible negative effects on the performance of the test people in secondary causes, e.g. in the area of the current motivation of the tested, psychosocial climate within the entire team, or in the atmosphere during the preparations for the testing and during the testing itself (Suchomel, 2003). Overall lower test results also in tests of general physical readiness in the same year could indicate one of those reasons.

Generally, we can record more significant differences of the results in the cross-country running test in long-term monitoring among the tested classes of talented youths in the East Bohemian region. The fluctuations of the results might suggest an imbalance of the monitored membership base of talented youths of the East Bohemian area during monitored years, and in general it can show the overall difficulty of identifying the talents and following work with them (Moravec, 1990).

Owing to the given hypothesis we are most interested in the problematics of tracking the trends of the performance through the longitudinal testing and evaluation of this trend in a selected test across all monitored categories and generally as a complex. As indicated by the performance curves of talented young orienteering runners from the most important region in the context of this sport sector in the Czech Republic, between 1997 and 2014 there were no positive trends in average performance in the given running test observed in none of the youth categories.

As the last but not least and in connection with the problematics of the monitoring the trends of performance, it is suitable to mention the fact that it is possible to detect the significant deterioration in the performance in the running test in recent years of the testing. Specifically, in the period of $2009-2013$ the data reflecting the significantly lower performance in the given test than in previous years of the testing (1997 - 2008) are detected in individual categories. In categories G12, B12 and G14 (3 km distance test), three worst average results of the complex long-term testing appear namely in the years $2009-2013$; in the category of the oldest boys B14 (5 km distance test) there are two worst average results since 1997, when the tests started. Conversely, some positive indication may be 2014, which, after some time the image appears better performance than in the previous five consecutive years. On the contrary, the year 2014 can be some positive indication, when, after longer time, we can detect better performance than in previous subsequent five years.

\section{CONCLUSIONS}

We assumed that the performance of all monitored categories in the cross-country running test will show a downward trend in the monitored period 1997 - 2014. The hypothesis was confirmed. Processed results of measurements, mapping the state of endurance skills of talented young people in the monitored region and period, demonstrate long-term deterioration of the physical readiness of selected categories of orienteering runners. Linear trends may also indicate a general correlation with social hypokinesia - the negative development in the field of physical fitness of modern humans due to lack of regular exercise, the way children and youths spend their free time, increasing number of young families following consumer lifestyle, or approaches to teaching physical education at schools. It may also be associated with a greater degree of unpopularity of endurance stress not only in the monitored age.

In the field of sports training for children and youth, the evaluated measurement's data and expressed conclusions can help to build a systematic training for young talents in orienteering, which will respond adequately to the long-term negative trend in preparation of pupils. Although we may assume, that 
particularly by applying of modern knowledge in the field of sports training (namely the development of endurance abilities of youth), but also by dynamically development of the psychological approach to sports preparation of young talents, the performance of pupils will gain positive, thus improving, trend (Perič, 2004), the results suggest that so far this is vice versa.

Thanks to the created methodology of comparing the results of talented pupils testing in orienteering, it will be possible to perform processing and interpretation of results in the coming years. The obtained results can be used for example to compare the talented pupils of different areas or orienteering sports clubs, eventually to compare with competitors from different sport sectors or with the general population.

The results of the longitudinal monitoring of talented pupils in the East Bohemian region during the years 1997 - 2014 reveal regressive tendencies in the field of testing of the endurance abilities. The coaches of youths should respond appropriately to this in their programme of sport training - especially by ingenious scheme of specialized training, by selecting and applying appropriate and effective means of motivation, and by at least partial individualization, that is taking the personal needs of individual athletes into account. Last but not least, the coaches can also respond by the effective development of general physical preparedness of children and youth as a basis for further increasing of the level of physical fitness in the process of executive training. To contribute primarily to the development of all-purpose health-related fitness and thus to the overall health must always belong to the priorities and to the fundamental aspects of work with children and youth.

\section{REFERENCES}

1. Hnízdil, J., Havel, Z., Černá, L., Horkel, V., Horklová, H., Kresta, J., ... Žák, M. (2012). Rozvoj a diagnostika vytrvalostních schopností. Ústí nad Labem: Pedagogická fakulta Univerzita J. E Purkyně.

2. Hnízdil, J., \& Kirchner, J. (2005). Orientační sporty. Praha: Grada Publishing.

3. Krištofič, J. (2006). Pohybová príprava dětí. Praha: Grada Publishing.

4. Máček, M., \& Radvanský, J. (2011) Fyziologie a klinické aspekty pohybové aktivity. Praha: Galén.

5. Máček, M., \& Vávra, J. (1988). Fyziologie a patofyziologie tělesné zátěže. Praha: Avicenum.

6. Měkota, K. (1995). UNIFITTEST (6-60). Test and Norms of Motor Performance and Physical Fitness in Youth and in Adult Age. Olomouc: VUP.

7. Měkota, K. \& Kovář, R. (1996). UNIFITTEST (6-60). Ostrava: Pedagogická fakulta Ostravské Univerzity.

8. Moravec, R. (1990). Telesný, funkčný rozvoj a pohybová výkonnost' 7-18-ročnej mládeže v ČSFR. Bratislava: Šport.

9. Neuman, J. (2003). Cvičení a testy obratnosti, vytrvalosti a síly. Praha: Portál.

10. Perič, T. (2004). Sportovní príprava dětí. Praha: Grada Publishing.

11. Perič, T. (2006). Výběr sportovních talentů. Praha: Grada Publishing.

12. Růžička, I. (2009). Identifikace talentů a práce s nimi. Orientační běh, 5, pp.9-10.

13. Růžička, I., \& Lamichová, K. (2010). Možnosti motorického testování v OB. Orientační běh, 1, pp.10-14.

14. Suchomel, A. (2003). Současné přístupy k hodnocení tělesné zdatnosti u dětí a mládeže. Česká kinatropologie, 7(1), pp.83-100.

15. Thomas, J.R., \& Nelson, J.K. (2001). Research methods in physical activity (4th ed). Champaign, IL: Human Kinetics. 